\title{
THE TEACHING OF ENGLISH FOR HOTEL AT NEPTUNE KEDIRI
}

\author{
Yulio Iswandaru Putra
}

\begin{abstract}
This research was carried out to answer three objectives of study. Those are the teaching of English for Hotel at Neptune Kediri, response of the students towards the teaching of English for Hotel at Neptune Kediri and the tutor's solution of the problems faced by students. The design was descriptive qualitative. The research instruments were observation sheet, interview note/sheet, document, and field note. The data collecting method were observation, interview, documentation, and field note. The result of this study showed that the teaching process of English for hotel at NEPTUNE had been supported by syllabus and lesson plan, the material was taken from book and internet, the media is using whiteboard and lcd tv. The method which was used was communicative learning and drill method, the technique which was applied in the class was direct question, problem based learning, discussion and role play technique. The evaluation of this program was taken by daily, mid semester and final semester. Tutor takes the student activeness and ability every meeting, mid and final evaluation take by interview test and witten test. From the result about the students' perception was known that students had problems in constructing idea for speaking, less vocabulary and less confidence. From the students' problem, the tutor gave solution by giving them tips and more discussion to increase their comprehension in speaking English.
\end{abstract}

Key Word: English hotel, ESP, teaching English

\section{INTRODUCTION}

ESP is centered on the language appropriate to the activities of a given discipline. Hutchinson and Waters in Javid (2015) ESP is an approach to language teaching in which all decisions as to content and method are based on the learner's reason for learning. Dudley Evansin Zohreh (2010) explains that ESP may not always focus on the language for one specific discipline or occupation, such as English for Law or English for Engineering.

English course design for the hotel industry relies on objectives and perceived needs of employers and the institution in compliance with specific English for the hotel industry, Standard Operating Procedure (SOP) of the hotel, or a specific group of hotel workers, regarding their real tasks and situations. An employer is not likely to be concerned much about the employees' real needs and wants butfocuses on the necessity of the functional English in order for the jobs to be successfully performed.

Cho (2005) believes that English for tourism is viewed as an area of business English and incorporate business English and English for academic 
purposes by bridging workplace communication and classroom use. This can help to increase the job opportunities in the international industry. Therefore, the function of English as a common language played a significant role in the hotel business, especially English for Specific Purposes (ESP). The officers of the hotel needed to prepare for English skill usage during working. In the hotel, English language commonly used as a second language not only to communicate with the foreign guests but it is also used in hotel brochures, room names, hotel facilities and other services. In the hotel business, English is used as the lingua Franca and it is the most commonly used languages in the hotel industry worldwide (Blue \& Harun, 2003).

English for tourism is known as one of the attractive subjects since many of the people will be a tourist at least once in their lifetime. According to Buhler (2000). In the world of hospitality, courtesy and accuracy in English speaking, in this case English for hotel, is part of the inevitable service in communicating with guests. Hotel guests will not complain about the language weaknesses of employees in communicating with them, but they will feel greatly appreciated and impressed if employees can communicate in a very polite and appropriate language. The hotel, and its employees, will get a positive rating from the guests. The problem is, not all hotel employees master the polite English for hotel. To master the English hospitality conversation material, there are several efforts that can be done one of them provide learning materials for English language. This study intends to answer the following questions

1. How is the teaching of English for Hotel at Neptune Kediri (in the term of syllabus, lesson plan, method, technique, media, material, teaching learning process, and evaluation model)?

2. How is the response of the students towards the the teaching of English for Hotel at Neptune Kediri (in the term of students' difficulties, perception on the teaching learning process, and the advantages)?

3. How is the tutor's solution of the problems faced by students (in the term of problem identification and solution)?

\section{RESEARCH METHOD}

The design of this study was descriptive qualitative to analyze the data. This study was conducted on May $8^{\text {th }}$ to $18^{\text {th }} 2018$ in NEPTUNE Kediri. It is located on K.H. Hashim Asyari street 49, Kediri, East Java. The subject of this research are the English hotel's tutor, head of academic department and the students. The tutor and head of academic departmentis the subject and main role in teaching and learning process. Meanwhile, the students are the object of English teaching.

To collect the data the researcher used instruments such as interview, questionnaire, observation checklist, field note and test. Interview was used to know information from the teacher's side. Meanwhile, the questionnaire, observation checklist and also field note was to collect data about teaching and learning process. The data obtained from observation and interviews were reduced by summarizing, choosing the important information, and classifying them based on the focus. In this research, the data reduced are the results of observation and 
interview related to the implementation of expert method in teaching and learning process.

\section{FINDING AND DISCUSSION}

\section{a. The teaching of English for Hotel at Neptune Kediri}

The Tutor always used syllabus in first meeting until fourth meetingin the form of book. Neptune has lesson plan has asame form with formal educational institution. Tutor used same method in first meeting until fourth meeting, the method used by tutor was communicative and drill method. The technique used by the tutor belong to free technique, in the first meeting was discussion technique, second meeting was problem based learning and role play, third meeting, was discussion technique,fourth meeting was problem based learning and role play while delivered asking $\&$ giving suggestion material in class. The media used in the first meeting until fourth meeting was white board and LCD screen. Material which was used for English hotel came from book and internet. There were two kind of evaluation in NEPTUNE, interview test and written test.

Table 1. Result of the teaching of English for Hotel

\begin{tabular}{|l|c|c|c|c|c|c|c|c|}
\hline \multirow{2}{*}{ Date } & & \multicolumn{7}{|c|}{ Sub Focus } \\
\cline { 2 - 9 } & Syllabus & $\begin{array}{l}\text { Lesson } \\
\text { plan }\end{array}$ & Method & Technique & Media & Material & $\begin{array}{l}\text { Teaching } \\
\text { process }\end{array}$ & Evaluation \\
\hline $\begin{array}{l}\text { Tuesday, } \\
8 \text { May 2018 }\end{array}$ & $\sqrt{ }$ & $\sqrt{ }$ & $\sqrt{ }$ & $\sqrt{ }$ & $\sqrt{ }$ & $\sqrt{ }$ & $\sqrt{ }$ & $\mathrm{x}$ \\
\hline $\begin{array}{l}\text { Friday, } \\
\text { 11 May 2018 }\end{array}$ & $\sqrt{ }$ & $\sqrt{ }$ & $\sqrt{ }$ & $\sqrt{ }$ & $\sqrt{ }$ & $\sqrt{ }$ & $\sqrt{ }$ & $\mathrm{x}$ \\
\hline $\begin{array}{l}\text { Tuesday, } \\
\text { 15 May 2018 }\end{array}$ & $\sqrt{ }$ & $\sqrt{ }$ & $\sqrt{ }$ & $\sqrt{ }$ & $\sqrt{ }$ & $\sqrt{ }$ & $\sqrt{ }$ & $\mathrm{x}$ \\
\hline $\begin{array}{l}\text { Friday, } \\
\text { 18 May 2018 }\end{array}$ & $\sqrt{ }$ & $\sqrt{ }$ & $\sqrt{ }$ & $\sqrt{ }$ & $\sqrt{ }$ & $\sqrt{ }$ & $\sqrt{ }$ & $\mathrm{x}$ \\
\hline
\end{tabular}

\section{b. Students' Response Towards the Teaching of English for Hotel}

Difficulties faced by students mostly constrained from the new vocabulary used in this vocational hotel, of course most of them have difficulty memorizing because just know or hear the vocabulary, maybe only a little know because have more experience in previous study in English course. Besides that, some of the students feel bored of course because already graduated from English course and mastering the material, while others who lack English language skills in the situation and conditions in the class feel less confident when learning or presentation in front of the class. Because the English hotel all the scope of English aimed at the hospitality of course many new vocabularies that has not been heard by student. In the class also taught how to handle the hotel guests, or face the problems at the hotel, of course students also learn to overcome these 
problems by interacting well, easy to do with the Indonesian language, but they have trouble doing it with English.

The student response from the English hotel class in NEPTUNE was good. They realize the importance of English and its use in the scope of tourism is very important, because of that they follow the class well in order to understand the lesson. Outside the classroom they also make their own study club and everything that has been taught by teachers makes them more confident to actively speak English. The English hotel class helps student to use English to interact using English well, because the field of hospitality of course many foreigners. For students it makes for better job opportunities for them.

Table 2. The response of the students toward the teaching of English for hotel

\begin{tabular}{|c|c|c|c|}
\hline \multirow{2}{*}{ Date } & \multicolumn{3}{|c|}{ Sub Focus } \\
\hline & Difficulties & Perception & Advantages \\
\hline $\begin{array}{l}\text { Tuesday, } \\
8 \text { May } 2018\end{array}$ & $\begin{array}{l}\text { A few students don't } \\
\text { know about the } \\
\text { material and less } \\
\text { confident while in } \\
\text { front of class }\end{array}$ & $\begin{array}{l}\text { Student like the class, } \\
\text { and follow the class } \\
\text { well although they } \\
\text { have difficult }\end{array}$ & $\begin{array}{l}\text { They get tips and } \\
\text { tricks from the tutor }\end{array}$ \\
\hline $\begin{array}{l}\text { Friday } \\
11 \text { May } 2018\end{array}$ & $\begin{array}{l}\text { Less confident and not } \\
\text { familiar about the } \\
\text { material }\end{array}$ & $\begin{array}{l}\text { Enjoy and follow well } \\
\text { the class }\end{array}$ & $\begin{array}{l}\text { They get tips and } \\
\text { tricks from the tutor }\end{array}$ \\
\hline $\begin{array}{l}\text { Tuesday, } \\
15 \text { May } 2018\end{array}$ & $\begin{array}{l}\text { Being shy in practicing } \\
\text { makes the students get } \\
\text { trouble in their } \\
\text { confidences }\end{array}$ & Have the curiosity & $\begin{array}{l}\text { They get tips and } \\
\text { tricks from the tutor }\end{array}$ \\
\hline $\begin{array}{l}\text { Friday, } \\
18 \text { May } 2018\end{array}$ & $\begin{array}{l}\text { Some students don't } \\
\text { know about the } \\
\text { material and less } \\
\text { confident while in } \\
\text { front of class }\end{array}$ & $\begin{array}{l}\text { Although get } \\
\text { difficulty, the students } \\
\text { still enjoy }\end{array}$ & $\begin{array}{l}\text { They get tips and } \\
\text { tricks from the tutor }\end{array}$ \\
\hline
\end{tabular}

\section{c. Tutor's Solution of the Problems Faced by Students}

From the problems of the student, there is a incentive class before the class, that goal is to introduce every lesson before learning in regular class, so the student can prepare themselves in order to followed the class well. To solve the problems about confidence, the tutor gave some directions and tips that could increase their spirit every day.

\section{CONCLUSION}

The teaching process of English for hotel had been supported by sets of equipment in learning such as syllabus, lesson plan, method, media, and material.The response of students toward the teaching of English hotel process were consist of three terms, they are students' difficulties, students' perception on 
teaching learning process, and the advantages which can be taken by following this class. The way of tutor's solution of the problems which are faced by students needed problem identification and solution.

\section{REFERENCES}

Blue, G.M \& Harun, M. 2003. Hospitality Language as a Professional Skill. English for Specific Purposes Pergamon Journal. (Online). http://www.elsevier.com. Accessed 11 March 2018

Buhler, K. 2000. Theory of Language: The Representational of Language. Amsterdam, Philadelphia: John Benjamins Publishing Company.

Cho, B. (2005). Usefulness and enjoyment of simulation activities for tourism major students. Modern English Education 6.1, 3-17.

Javid, Choudhary Zahid.2015. English for Specific Purpose: Role of Learner, Teacher, Teacher and Teaching Methodologies. European Scientific Journal

Zohreh, E.2010. A Needs Analysis Approach to English For Specific Purpose in Iran. Texas University. USA 